\title{
AKTIVITAS ANTIINFLAMASI EKSTRAK DAUN TEMBELEKAN (Lantana Camara Linn) PADA TIKUS PUTIH (Rattus Norvegicus)
}

\author{
Aji Yudha Wijaya*, Muhammad Amir Masruhim, Hadi Kuncoro \\ Laboratorium Penelitian dan Pengembangan Kefarmasian, Farmaka Tropis, Fakultas Farmasi, Universitas \\ Mulawarman, Samarinda, Kalimantan Timur \\ *Corresponding author email : Ajiyuda.yohoho@gmail.com
}

\begin{abstract}
A study of anti-inflammatory activity of tembelekan leaf extract (Lantana Camara Linn) in white rat (Rattus norvegicus) has done. This study aimed to determine the effective doses of Tembelekan leaf extract which giving an anti-inflammatory effect artificial edema in the feet of rat. The metode were artificial edema formatting and measuring the volume of white rat feet an o regular basis by a pletismometer. The used doses were $750 \mathrm{mg} / \mathrm{kgBB}, 1000 \mathrm{mg} / \mathrm{kgBB}, 1250 \mathrm{mg} / \mathrm{kgBB}$ dan $1500 \mathrm{mg} / \mathrm{kgBB}$. The data were further processed by using analysis of variance (Anova) two away, advance testing HSD test (Honestly Significance Difference Duncan). The result of this research is the effective dose of tembelekan leaf extract is $1500 \mathrm{mg} / \mathrm{kgBB}$ wich as an anti-inflammatory effect better than $750 \mathrm{mg} / \mathrm{kgBB}, 1000 \mathrm{mg} / \mathrm{kgBB}, 1250 \mathrm{mg} / \mathrm{kgBB}$.
\end{abstract}

Keywords: tembelekan leaf extract (Lantana Camara Linn), anti-inflammatory activity, white rat (Rattus norvegicus)

\begin{abstract}
ABSTRAK
Telah dilakukan penelitian aktivitas antiinflamasi akstrak daun tembelekan (Lantana Camara Linn) pada tikus putih (Rattus Norvegiens). Penelitian ini bertujuan untuk mengetahui berapa dosis efektif dari ekstrak daun tembelekan yang memberikan efek antiinflamasi paling baik terhadap edema buatan pada telapak kaki tikus putih. Penelitian menggunakan metode pembentukan edema buatan dan mengukur volume kaki tikus putih secara berkala dengan menggunakan alat pletismometer. Dosis yang digunakan untuk ekstrak adalah $750 \mathrm{mg} / \mathrm{kgBB}, 1000 \mathrm{mg} / \mathrm{kgBB}, 1250 \mathrm{mg} / \mathrm{kgBB}$ dan $1500 \mathrm{mg} / \mathrm{kgBB}$. Data hasil penelitian selanjutnya diolah dengan menggunakan analisis varian (Anava) dua arah, pengujian lanjutan uji BNJD (Beda Nyata Jujur Duncan). Hasil peneltian yang dihasilkan adalah dosis efektif ekstrak daun tembelekan yaitu $1500 \mathrm{mg} / \mathrm{kgBB}$ yang memiliki aktivitas antiinflamasi paling baik dibandingkan dengan dosis $750 \mathrm{mg} / \mathrm{kgBB}, 1000 \mathrm{mg} / \mathrm{kgBB}$, $1250 \mathrm{mg} / \mathrm{kgBB}$.
\end{abstract}

Kata Kunci :Ekstrak daun tembelekan, (Lantana Camara Linn), aktivitas antiinflamasi, tikus putih (Rattus norvegicus)

Submitted on: 17 Januari $2017 \quad$ Accepted on: 4 March 2017

DOI: https://doi.org/10.25026/jsk.v1i6.63

\section{PENDAHULUAN}

Inflamasi merupakan suatu respon protektif normal terhadap luka jaringan yang disebabkan oleh trauma fisik, zat kimia yang merusak, atau zat-zat mikrobiologik. Inflamasi adalah usaha tubuh untuk menginaktifasi atau merusak organisme yang menyerang, menghilangkan dan mengatur derajat perbaikan jaringan [1]. Proses inflamasi merupakan suatu mekanisme perlindungan tubuh untuk menetralisir dan membasmi agen-agen yang berbahaya pada tempat cidera dan mempersiapkan keadaan untuk perbaikan jaringan misalnya antigen, virus, bakteri, protozoa [2]. 
Umumnya, kemerahan atau rubor merupakan hal pertama yang terlihat di daerah yang mengalami peradangan. Saat reaksi peradangan timbul, meningkatnya permaebilitas kapiler dengan migrasi leukosit menuju jaringan radang [3]. Tanda-tanda dari proses radang antara lain rubor, kalor, dan tumor pada inflamasi akut terjadi karena peningkatan aliran darah dan edema [4].

Salah satu tumbuhan yang dapat digunakan dan berkhasiat obat adalah daun Tembelekan. Tembelekan telah lama dikenal oleh masyarakat Indonesia dan mempunyai banyak khasiat diantaranya, pereda demam, penyakit kulit, penghilang nyeri, keputihan, menghilangkan bengkak, obat batuk, TBC, dan asma. Tumbuhan ini merupakan salah satu spesies dari famili Verbenaceae. Verbenaceae mengandung senyawa metabolit sekunder seperti flavonoid, terpenoid, alkaloid, minyak atsiri, dan senyawa kecil lainnya seperti saponin dan tannin [5].

Daun tembelekan marupakan tanaman yang berkhasiat obat, salah satunya sebagai antiinflamasi. Daun tunggal, berhadapan, bundar telur, ujung runcing, pangkal tumpul, tepi bergerigi, pertulangan menyirip, kedua permukaan berambut, perabaan kasar, panjang $5-8$ $\mathrm{cm}$, lebar $3,5-5 \mathrm{~cm}$, warnanya hijau tua [5]. Daun tembelekan yang telah diteliti dengan metode fitokimia kualitatif mengandung senyawa fenol, saponin, dan steroid (triterpenoid) [6]. Menurut Dalimartha, daun tembelekan mengandung flavonoid, terpenoid, alkaloid, minyak atsiri, dan senyawa seperti pitosterol, saponin dan tannin [5].

Senyawa metabolit sekunder dalam tumbuhan merupakan hasil sintesis yang terjadi dalam tumbuhan itu sendiri. Di dalam tubuh tumbuhan terjadi sintesis senyawa organik yang kompleks dan menghasilkan sederet golongan senyawa dengan berbagai macam struktur. Senyawa metabolit sekunder sangat bervariasi jumlah dan jenisnya dari setiap tumbuh-tumbuhan [8].

Dalam rangka usaha pengembangan dan pemanfaatan tumbuhan Tembelekan (L. camara) sebagai obat tradisional yang telah digunakan secara luas oleh masyarakat, maka perlu dilakukan penelitian untuk pendayagunaan potensi sumber daya alam, dengan melakukan pengujian terhadap aktifitas antiinflamasi dari ekstrak daun tembelekan.

\section{METODE PENELITIAN}

\section{Bahan}

Daun tembelekan (Lantana Camara Linn); pelarut metanol; air suling; natrium $\mathrm{CMC}$; karagenan; $\mathrm{NaCl}$

\begin{abstract}
Alat
Pletismometer; timbangan hewan; spoid oral; spoid injeksi; peralatan gelas; labu takar; batang pengaduk; penangas air; cawan porselen; dan Inkubator.
\end{abstract}

\section{Prosedur Penelitian}

Sebelum pengujian, tikus dipuasakan selama 18 jam dengan tetap diberi air minum. Tikus putih yang digunakan sebanyak 15 ekor yang telah dibagi menjadi lima kelompok, masingmasing kelompok terdiri dari 3 ekor tikus putih. Kelompok pertama sebagai kontrol negatif hanya diberikan suspensi Na.CMC 1\% dalam air suling secara oral. Kelompok kedua sampai kelima sebagai kelompok uji diberi ekstrak daun tembelekan dengan variasi dosis yang berbeda yaitu pada kelompok kedua diberi dosis ekstrak daun tembelekan $750 \mathrm{mg} / \mathrm{kgBB}$, kelompok ketiga dosis ekstrak daun tembelekan $1000 \mathrm{mg} / \mathrm{kgBB}$, kelompok keempat dosis ekstrak daun tembelekan $1250 \mathrm{mg} / \mathrm{kgBB}$ dan kelompok 
yang kelima dosis ekstrak daun tembelekan $1500 \mathrm{mg} / \mathrm{kgBB}$ diberi secara oral.

Saat hari pengujian, masingmasing hewan ditimbang dan diberi tanda pada kaki kirinya, kemudian kaki kiri tikus diukur dengan menggunakan pletismometer. Hasil pengukuran telapak kaki ini merupakan nilai volume awal $\left(\mathrm{V}_{0}\right)$ yaitu volume kaki tikus sebelum diinduksi menggunakan karagenan. Setelah pengukurn awal, masing-masing tikus diberi suspensi bahan uji secara oral sesuai dengan kelompoknya. Satu jam kemudian, kepada masing-masing telapak kaki tikus disuntik secara subkutan intraplantar dengan $0,1 \mathrm{~mL}$ larutan karagenan $1 \%$. Setelah 30 menit, dilakukan lagi pengukuran volume kaki tikus. Perubahan volume telapak kaki tikus yang terjadi dicatat sebagai volume kaki tikus waktu ke-t $\left(\mathrm{V}_{\mathrm{t}}\right)$. Pengukuran dilakukan setiap 30 menit.Volume radang adalah selisih volume kaki tikus setelah dan sebelum disuntikkan karagenan.

\section{HASIL DAN PEMBAHASAN}

Dalam penelitian antiinflamasi, ada beberapa hewan yang dapat digunakan sebagai obyek penelitian, salah satunya adalah tikus yang telah dibuat radang menggunakan berbagai pemicu kimiawi salah satunya menggunakan karagenin. Pengunaan karagenin memiliki beberapa keuntungan, antara lain tidak meninggalkan bekas, tidak menimbulkan kerusakan jaringan, dan memberikan respon lebih peka terhadap obat antiinflamasi dibanding senyawa iritan lainnya [7].

Pembentukan radang oleh karagenan menghasilkan peradangan akut, dan tidak menyebabkan kerusakan jaringan, meskipun radang dapat bertahan selama 360 menit dan berangsur-angsur berkurang selama satu hari. Karagenan sebagai penyebab radang dapat dipengaruhi oleh obat inflamasi. Responnya terhadap obat inflamasi lebih peka dibanding dengan iritan lainnya [9].

Sebelum menentukan variasi dosis, peneliti melakukan uji pendahuluan dengan menggunakan dosis $750 \mathrm{mg} / \mathrm{kgBB}$ dan $1000 \mathrm{mg} / \mathrm{kgBB}$. Pada uji pendahuluan ini dosis yang dipakai menunjukan penurunan radang pada kaki tikus putih. Setelah dilakukan uji pendahuluan peneliti menentukan 4 variasi dosis yang dipakai, yaitu; $750 \mathrm{mg} / \mathrm{kgBB}, \quad 1000 \mathrm{mg} / \mathrm{kgBB}$, $1250 \mathrm{mg} / \mathrm{kgBB}$ dan $1500 \mathrm{mg} / \mathrm{kgBB}$. Dengan menggunakan 3 replikasi tikus putih. Selain variasi dosis dilakukan juga pengujian antiinflamasi dengan kontrol negatif suspensi Na-CMC sebagai pembanding.

Pengujian ini dilakukan dengan mengukur perubahan diameter radang pada telapak kaki tikus putih yang sebelumnya diinduksi karagenan $1 \%$ sebanyak $0,1 \mathrm{ml}$ ketelapak kaki tikus putih secara intraplantar. Metode pembentukan peradangan buatan adalah salah satu metode pengujian aktivitas antiinflamasi berdasarkan kemampuan agen tersebut untuk menghambat produksi radang di kaki tikus setelah injeksi agen radang yang kemudian diukur volume radang. Volume radang diukur sebelum dan sesudah pemberian zat yang diuji. Beberapa iritan yang dipakai sebagai penginduksi radang antara lain formalin, kaolin, ragi, dekstran, dan karagenan. Hasil pengujian dapat dilihat secara visual. Data hasil penelitian dapat dilihat pada tabel 1 dan gambar 1 .

Untuk mengetahui ada perbedaan dari setiap perlakuan pada kelompok dosis pemberian ekstrak hewan coba, dilakukan analisis varians (ANAVA) dua arah yang hasil perhitungannya dapat dilihat pada tabel 2 . 
Berdasarkan tabel 2. diperoleh $\mathrm{F}$ hitung dosis $>\mathrm{F}$ tabel, $\mathrm{F}$ hitung waktu > $\mathrm{F}$ tabel, $\mathrm{F}$ hitung interaksi $>\mathrm{F}$ tabel pada taraf $1 \%$ dan $5 \%$ dimana nilai $\mathrm{F}$ hitung dosis 8,33 , F hitung waktu 3,66, dan F hitung interaksi 6,66. Hal ini berarti bahwa ekstrak daun tembelekan dengan variasi dosis $750 \mathrm{mg} / \mathrm{kgBB}$, $1000 \mathrm{mg} / \mathrm{kgBB}, \quad 1250 \mathrm{mg} / \mathrm{kgBB}$ dan $1500 \mathrm{mg} / \mathrm{kgBB}$ signifikan pengaruh perbedaan dosis dan signifikan pengaruh waktu pada taraf $5 \%$ dan $1 \%$.

Hasil signifikan dari data anava dua arah tersebut dilanjutkan dengan pengujian lanjutan digunakan uji Beda Nyata Jujur Duncan (BNJD) karena didapatkan Koefisien Keseragaman (KK) dosis sebesar 19,75\% untuk mengetahui dosis yang paling memiliki pengaruh atau memiliki aktivitas antiinflamasi paling baik.

Tabel 1.Hasil pengujian aktivitas antiinflamasi daun tembelekan

\begin{tabular}{cccccc}
\hline \multirow{2}{*}{ Waktu } & \multicolumn{5}{c}{ Volume kaki tikus kontrol dan dosis uji $(\mathrm{mL})$} \\
\cline { 2 - 5 } & Kontrol Negatif & $750 \mathrm{mg} / \mathrm{kgBB}$ & $1000 \mathrm{mg} / \mathrm{kgBB}$ & $1250 \mathrm{mg} / \mathrm{kgBB}$ & $1500 \mathrm{mg} / \mathrm{kgBB}$ \\
\hline Kaki awal & 0,012 & 0,010 & 0,011 & 0,010 & 0,010 \\
1 jam & 0,014 & 0,012 & 0,013 & 0,012 & 0,013 \\
2 jam & 0,016 & 0,014 & 0,014 & 0,014 & 0,014 \\
3 jam & 0,016 & 0,014 & 0,015 & 0,014 & 0,013 \\
4 jam & 0,017 & 0,013 & 0,014 & 0,012 & 0,010 \\
5 jam & 0,016 & 0,011 & 0,013 & 0,010 & 0,010 \\
6 jam & 0,015 & 0,011 & 0,011 & 0,010 & 0,010 \\
\hline
\end{tabular}

Keterangan:

Kelompok I $\quad$ : Sebagai kontrol negatif diberi suspense natrium CMC $1 \%$

Kelompok II : : Suspensi ekstrak daun tembelekan dengan dosis $750 \mathrm{mg} / \mathrm{kgBB}$

Kelompok III $\quad$ : Suspensi ekstrak daun tembelekan dengan dosis $1000 \mathrm{mg} / \mathrm{kgBB}$

Kelompok IV :Suspensi ekstrak daun tembelekan dengan dosis $1250 \mathrm{mg} / \mathrm{kgBB}$

Kelompok $V \quad$ : Suspensi ekstrak daun tembelekan dengan dosis $1500 \mathrm{mg} / \mathrm{kgBB}$

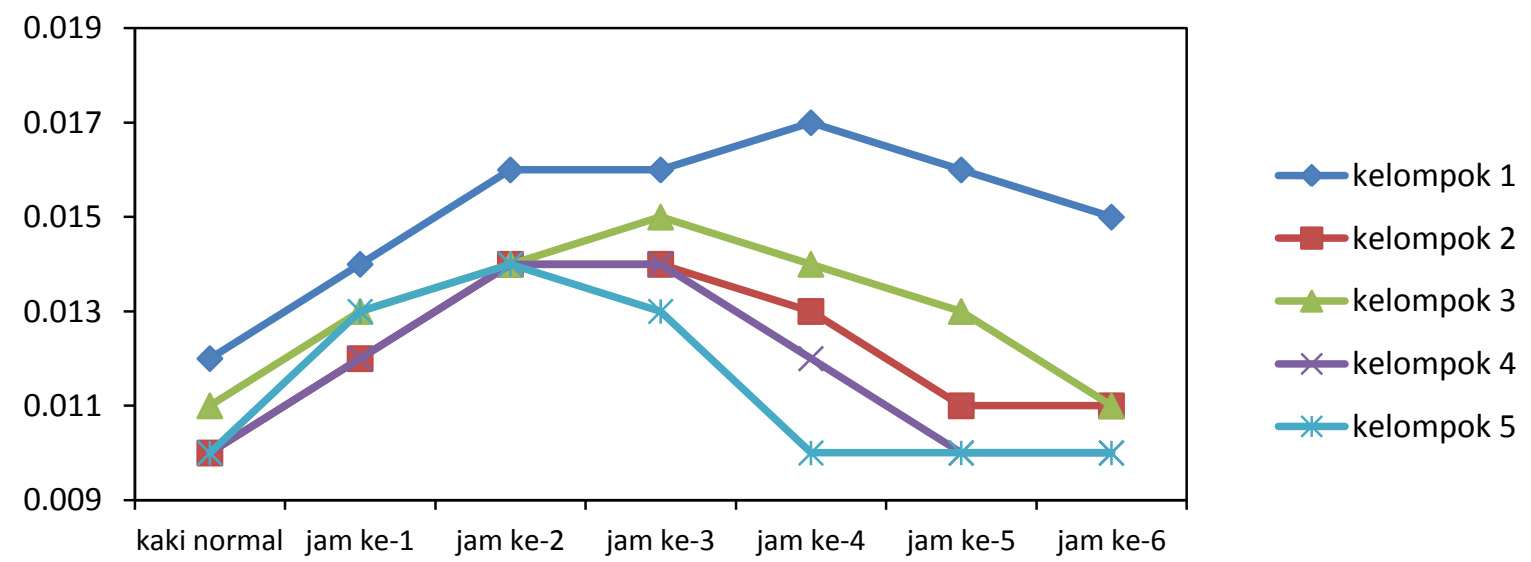

Keterangan:

Kelompok I : Sebagai kontrol negatif diberi suspense natrium CMC 1\%

Kelompok II : : Suspensi ekstrak daun tembelekan dengan dosis $750 \mathrm{mg} / \mathrm{kgBB}$

Kelompok III : : Suspensi ekstrak daun tembelekan dengan dosis $1000 \mathrm{mg} / \mathrm{kgBB}$

Kelompok IV : Suspensi ekstrak daun tembelekan dengan dosis $1250 \mathrm{mg} / \mathrm{kgBB}$

Kelompok $V \quad$ : Suspensi ekstrak daun tembelekan dengan dosis 1500mg/kgBB 
Tabel 2.Data Anava dua arah ekstrak daun tembelekan

\begin{tabular}{ccccccc}
\hline \multirow{2}{*}{$\begin{array}{c}\text { Sumber } \\
\text { variasi }\end{array}$} & Jumlah Kuadrat & Db & Kuadrat Tengah & Fhitung & \multicolumn{2}{c}{ Ftabel } \\
\cline { 5 - 7 } & & & & & $5 \%$ & $1 \%$ \\
Dosis & 0,00020 & 4 & 0,00005 & 8,33 & $2,50^{*}$ & $3,60^{* *}$ \\
waktu & 0,00012 & 5 & 0,00002 & 3,66 & $2,35^{*}$ & $3,29^{* *}$ \\
Interaksi & 0,00008 & 20 & 0,000004 & 6,66 & $1,70^{*}$ & $2,44^{* *}$ \\
Galat & 0,00006 & 70 & 0,000006 & & & \\
Total & 0,00046 & 99 & & & & \\
\hline Keterangan : * = Signifikan ** = Sangat signifikan & & &
\end{tabular}

Tabel 3. Data Uji lanjutan uji Beda Nyata Jujur Duncan (BNJD) penurunan inflamasi terhadap dosis

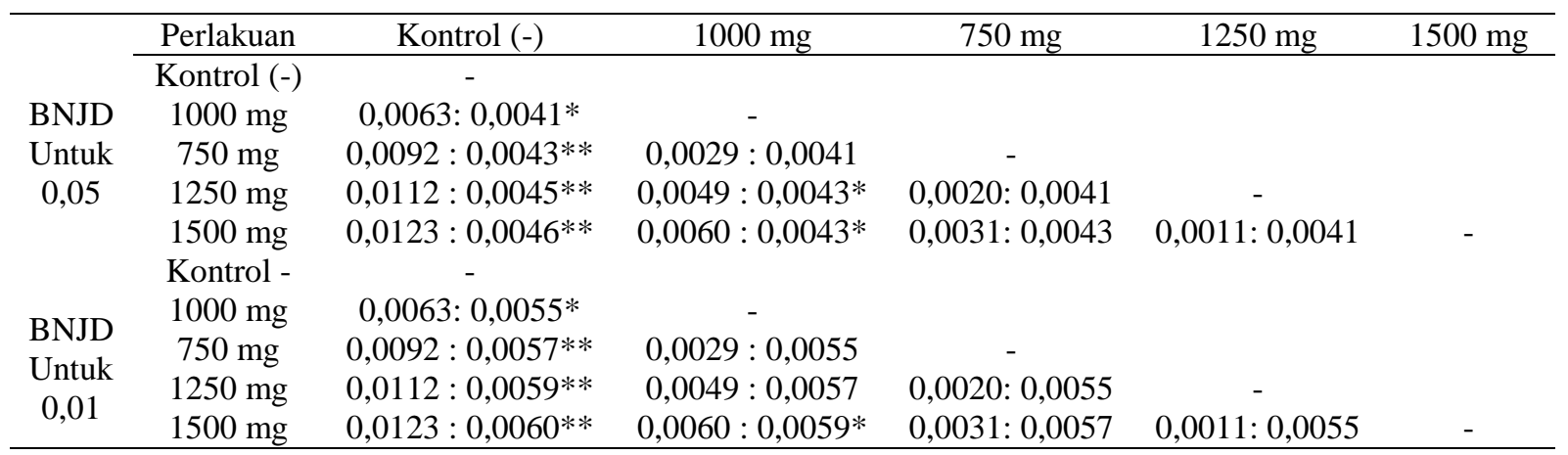

Keterangan : $*=$ Signifikan $* *=$ Sangat signifikan

Tabel 4. Data Uji lanjutan uji Beda Nyata Jujur Duncan (BNJD) penurunan inflamasi terhadap waktu

\begin{tabular}{|c|c|c|c|c|c|c|c|}
\hline & Perlakuan & 2 jam & 3 jam & 4 jam & 1 jam & 5 jam & 6 jam \\
\hline & 2 jam & - & & & & & \\
\hline BNJD & 3 jam & 0,0006: 0,0041 & - & & & & \\
\hline Untuk & 4 jam & $0,0042: 0,0043$ & $0,0036: 0,0041$ & - & & & \\
\hline \multirow[t]{5}{*}{0,05} & $1 \mathrm{jam}$ & $0,0048: 0,0045^{*}$ & $0,0042: 0,0043$ & 0,0006: 0,0041 & - & & \\
\hline & 5 jam & $0,0078: 0,0046^{* *}$ & $0,0072: 0,0045^{*}$ & $* 0,0036: 0,0043$ & 0,0030: 0,0041 & - & \\
\hline & $6 \mathrm{jam}$ & $0,0096: 0,0047 * *$ & $0,0090: 0,0046^{*}$ & $* 0,0054: 0,0045 *$ & 0,0048: $0,0043^{*}$ & 0,0018:0,0041 & - \\
\hline & 2 jam & - & & & & & \\
\hline & 3 jam & 0,0006: 0,0055 & - & & & & \\
\hline BNJD & 4 jam & $0,0042: 0,0057$ & $0,0036: 0,0055$ & - & & & \\
\hline Untuk & $1 \mathrm{jam}$ & $0,0048: 0,0059$ & $0,0042: 0,0057$ & 0,0006: 0,0055 & - & & \\
\hline \multirow[t]{2}{*}{0,01} & $5 \mathrm{jam}$ & $0,0078: 0,0060 * *$ & $0,0072: 0,0059^{*}$ & *0,0036: 0,0057 & 0,0030: 0,0055 & - & \\
\hline & $6 \mathrm{jam}$ & $0,0096: 0,0061 * *$ & $0,0090: 0,0060 *$ & $* 0,0054: 0,0059$ & 0,0048: 0,0057 & 0,0018:0,0055 & \\
\hline
\end{tabular}

Keterangan : $*=$ Signifikan $* *=$ Sangat Signifikan

Hasil perhitungan uji lanjutan uji Beda Nyata Jujur Duncan (BNJD) dapat dilihat pada tabel 3. Dari hasil data pada tabel 3 dapat dilihat dari 4 variasi dosis mendapatkan hasil yang signifikan jika dibandingkan dengan kontrol negatif pada taraf 0,05 dan 0,01. Pada dosis $1500 \mathrm{mg} / \mathrm{kgBB}$ dan $1250 \mathrm{mg} / \mathrm{kgBB}$ lebih signifikan dibandingkan dengan dosis $1000 \mathrm{mg} / \mathrm{kgBB}$ pada taraf 0,05 , Sedangkan pada taraf 0,01 hanya dosis $1500 \mathrm{mg} / \mathrm{kgBB}$ yang signifikan dibanding 
dengan dosis $1000 \mathrm{mg} / \mathrm{kgBB}$. Jadi dapat disimpulkan bahwa dosis efektif ekstrak daun tembelekan $1500 \mathrm{mg} / \mathrm{kgBB}$ yang memiliki aktivitas antiinflamasi lebih baik pada penurunan radang kaki tikus tikus putih.

Dari tabel 4 dapat dilihat dari tabel bahwa pada jam ke-5 beberapa dosis mulai bereaksi dalam penurunan radang dan pada jam ke-6 semua kelompok uji dan kontrol negatif mengalami penurunan radang pada kaki tikus putih. Jadi dapat disimpulkan bahwa pada ekstrak tembelekan ada pengaruh waktu dalam penyembuhan antiinflamasi kaki kiri tikus putih.

\section{KESIMPULAN}

Dari empat varians dosis ekstrak daun Tembelekan $750 \mathrm{mg} / \mathrm{kgBB}$, $1000 \mathrm{mg} / \mathrm{kgBB}, \quad 1250 \mathrm{mg} / \mathrm{kgBB}$ dan $1500 \mathrm{mg} / \mathrm{kgBB}$. Didapat dosis efektif ekstrak daun tembelekan $1500 \mathrm{mg} / \mathrm{kgBB}$ yang memiliki aktivitas antiinflamasi lebih baik pada penurunan radang kaki tikus putih

\section{DAFTAR PUSTAKA}

[1]. Mycek, M.J., Harvey,R.A., Champe, P.A. 2001. Farmakologi Ulasan Bergambar edisi kedua. Jakarta; Penerbit Widya Medika

[2]. Katzung, B.G. 2002. Farmakologi Dasar dan Klinik. Jakarta; Penerbit Salemba

[3]. Tanu, Syarif A., Estuningtyas A., Setiawati A., Muchtar H.A., dan Arif A., 2002, Farmakologi dan Terapi, FKUI; Jakarta

[4]. Kumar, V., A.K., Fausto N., dan Mitchell R.N., 2007, Robbins Basic Pathology, Philadelpia

[5]. Dalimartha, Setiawan. 2008. Atlas Tumbuhan Obat Indonesia Jilid 1. Trubus Agriwidya: Jakarta

[6]. Swantika, I.B. 2011. Identifikasi Metabolit Sekunder dan Uji Bioaktivitas Ekstrak Daun Tembelekan ( Camara Linn) Terhadap Larva Udang (Artemia salina Leach). Fakultas Farmasi Universitas Mulawarman: Samarinda

[7]. Borgi, Via G, 2003. Instruction Manual Plethymometer. Italy; Comerio-Varese

[8]. Sastrohamidjojo, H. 1996. Sintesis Bahan Alam. Gadjah Mada University Press: Yogyakarta.

[9]. Tri Wardhana K. 2009. Uji Efek Antiinflamasi sedian Topikal Ekstrak Etanol dan Etil Asetat Rimpang Tumbuhan Kunyit terhadap mencit. Universitas Sumatra Utara: Medan 